\title{
INTERNET, MEMÓRIA E APRENDIZAGEM: TECNOLOGIAS DIGITAIS E IMPLICAÇÕES NA MEMÓRIA
}

\author{
INTERNET, MEMORIA Y APRENDIZAJE: TECNOLOGÍAS DIGITALES E \\ IMPLICACIONES EN LA MEMORIA
}

\author{
INTERNET, MEMORY AND LEARNING: DIGITAL TECHNOLOGY AND THE \\ IMPLICATIONS IN MEMORY
}

Melanie Retz Godoy dos Santos ZWICKER ${ }^{1}$

RESUMO: O desenvolvimento humano está em grande parte ligado às tecnologias e ao conhecimento acumulado de cada época. O ser humano faz instrumentos, fabrica utensílios, convive com uma determinada técnica que torna a sua circunstância peculiar. Tecnologia e sociedade estão intrinsecamente ligadas e a internet, também chamada web 2.0, é a expressão mais evidente do nosso momento sócio-cultural-tecnológico. Essa tecnologia comunicacional, que foi revolucionária, está hoje fortemente arraigada ao cotidiano, invadindo praticamente todos os setores da vida. O objetivo do trabalho é demonstrar, por meio de um estudo de caso com entrevistas em profundidade com usuários da rede, que as transformações fomentadas por ela - novas relações espaciotemporais, formas de sociabilidade, o acesso a grandes quantidades de informações e interatividade - modificaram de forma radical hábitos e comportamentos, formas de comunicar, interagir e aprende, além de criarem uma relação de extrema dependência com esse meio. Em decorrência, vale ressaltar que a internet está cada vez mais presente na memória de seus usuários, nas suas recordações e vivências individuais e também tem grande influência na formação da memória social. Ao alterar a vida cotidiana e seus processos comunicacionais, ela altera também formas de pensar, visões de mundo e tem importante papel na criação, manutenção e desenvolvimento do simbólico, o que contribui com a formação da memória coletiva. A Internet vive em uma espécie de retroalimentação com a memória coletiva: influencia as memórias de seus usuários e, ao mesmo tempo, alimenta-se repetidamente do imaginário e da memória social.

PALAVRAS-CHAVE: Tecnologia. Internet. Memória. Aprendizagem.

RESUMEN: El desarrollo humano está en gran parte ligado a las tecnologías y al conocimiento acumulado de cada época. El ser humano hace instrumentos, fabrica utensilios, convive con una determinada técnica que hace su peculiar circunstancia. Tecnología y sociedad están intrínsecamente conectadas y la Internet, también llamada web 2.0, es la expresión más evidente de nuestro momento socio-cultural-tecnológico. Esta tecnología comunicacional, que fue revolucionaria, está hoy fuertemente arraigada a lo cotidiano, invadiendo prácticamente todos los sectores de la vida. El objetivo del trabajo es demostrar, a través de un estudio de caso con entrevistas en profundidad con usuarios de la red, que las transformaciones fomentadas por ella -

${ }^{1}$ Universidade Estadual Paulista (Unesp), Bauru - SP - Brasil. Doutoranda em Mídia e Tecnologia. Mestre em Comunicação. Unesp/FAAC. E-mail: melanie.retz@gmail.com.

RPGE- Revista on line de Política e Gestão Educacional, Araraquara, v.21, n.esp.3, p. 1638-1654, dez., 2017. 
nuevas relaciones espacio-temporales, formas de sociabilidad, el acceso a grandes cantidades de información e interactividad - Han cambiado radicalmente hábitos y comportamientos, formas de comunicar, interactuar y aprender, además de crear una relación de extrema dependencia con ese medio. En consecuencia, vale resaltar que Internet está cada vez más presente en la memoria de sus usuarios, en sus recuerdos y vivencias individuales y también tiene gran influencia en la formación de la memoria social. Al cambiar la vida cotidiana y sus procesos comunicacionales, ella cambia también formas de pensar, visiones de mundo y tiene un papel importante en la creación, el mantenimiento y el desarrollo de lo simbólico, lo que contribuye a la formación de la memoria colectiva. La Internet vive en una especie de retroalimentación con la memoria colectiva: influye en las memorias de sus usuarios y al mismo tiempo se alimenta repetidamente de lo imaginario y de la memoria social.

PALABRAS-CLAVE: Tecnología. Internet. Memoria. Aprendizaje.

ABSTRACT: Human development is largely linked to the technologies and the accumulated knowledge of the time. The human being makes instruments, manufactures appliances, coexists with a certain technique that makes a peculiar circumstance. Technology and society are inextricably linked to the Internet, also called web 2.0, and it is the most evident expression of our socio-cultural and technological moment. This communication technology, which was revolutionary, is now strongly rooted in daily activities, invading life in many ways. The objective of this research was to show, through a case study with in-depth interviews with network users, the changes caused by it - new relations with time and space, forms of sociability, access to large amounts of information and interactivity - they changed radically habits and behaviors, ways to communicate, interact and learning and created an extreme dependency relationship with this medium. As a result, the internet is increasingly in memory of its members in their memories and individual experiences and it also has a great influence on the formation of social memory. By changing the everyday life and its communication processes, it also changes ways of thinking, worldviews and plays an important role in the creation, maintenance and development of the symbolic life, which contributes to the formation of collective memory. Internet lives in a kind of feedback loop with the collective memory: influences the memories of its members and at the same time, feeds repeatedly imaginary and social memory.

KEYWORDS: Technology. Internet. Memory. Learning.

\section{Introdução}

A internet, como ferramenta tecnológica, tem provocado mudanças profundas na sociedade atual, tanto em âmbito social, econômico, cultural, quanto nas formas de comunicar e aprender. Amplamente apropriada por seus usuários, ela está fortemente arraigada ao cotidiano deles, contaminando praticamente todos os setores da vida e deixando marcas na memória deles. O objetivo do trabalho é demonstrar quais as transformações proporcionadas pela internet e como elas modificaram hábitos e 
comportamentos, maneiras de comunicar e interagir e criaram uma relação de extrema dependência com esse meio. Além disso, o estudo também teve o intuito de registrar vivências e recordações marcantes dos usuários envolvendo a Internet e discutir sua possível utilização como um suporte para a memória coletiva. O trabalho foi dividido em três fases: pesquisa bibliográfica; pesquisa de campo e análise dos resultados. Considerando que não pretendíamos quantificar o número de comunicadores que utilizam a Internet e sim compreender a influência dela no cotidiano dos profissionais na cidade de Bauru-SP, suas impressões sobre esse meio e suas vivências marcantes envolvendo essa tecnologia, concluímos que o método mais adequado para essa investigação seria uma pesquisa qualitativa, mais especificamente um estudo de caso. Esse tipo de estudo é profundo, mas não amplo, procurando conhecer poucos elementos de uma população sob um grande número de aspectos (MATTAR, apud TRUJILLO, 2001, p.13-14). O método escolhido para a coleta de dados foi a entrevista semiestruturada em profundidade, que possibilita flexibilidade de dados e permite a liberdade de expressão e o aprofundamento da qualidade das informações. Segundo Lehmann (apud TRUJILLO, 2001, p. 44), uma entrevista em profundidade consiste em fazer perguntas dirigidas a um só sujeito por um só entrevistador, que tenta continuamente superar as respostas superficiais formulando novas questões que levam a respostas mais específicas.

\section{Desenvolvimento humano e tecnologia}

O desenvolvimento humano está em grande parte ligado às tecnologias e ao conhecimento acumulado de cada época. O ser humano faz instrumentos, fabrica utensílios, convive com uma determinada técnica que torna a sua circunstância peculiar. Podemos dizer que tecnologia e sociedade estão intrinsecamente ligadas: a sociedade cria novas tecnologias e, concomitantemente, é transformada por elas. De acordo com Castells (1999, p. 25), “a tecnologia é a sociedade e a sociedade não pode ser entendida ou representada sem as suas ferramentas tecnológicas". Como ressalta Ortega y Gasset (1989, p. 43), "houvéramos nascido cem anos antes, ainda que possuindo o mesmo caráter e iguais dons, o drama de nossas vidas seria muito diferente". Isso porque, "toda mudança do mundo, do horizonte, traz consigo uma mudança na estrutura do drama vital". Por exemplo, de que maneira podemos compreender o nomadismo do homem da Idade da Pedra lascada sem levar em consideração sua cultura material e seu 
desconhecimento da agricultura, que o fazia peregrinar em busca de alimentos? Da mesma forma, não se pode entender a transformação social e o progresso das grandes navegações no século XV se não apreciarmos a evolução técnica que a proporcionou: embarcações melhores (como a caravela, que é bem mais fácil de manobrar), a utilização da vela triangular (que permitia navegar contra o vento com rapidez), a criação do astrolábio (que fornecia orientação através do sol) e da bússola.

Há que se considerar ainda a influência direta ou indireta da técnica nos modos de pensar de cada época: Nicolau Copérnico (1473-1543) transformou a visão de mundo do seu tempo ao criar o sistema heliocêntrico, ou seja, ao revelar que o centro do sistema não era a Terra e sim o sol - contestando o que sugeria o astrônomo grego Ptolomeu (1564-1642). Galileu Galilei foi ainda mais longe: ao aperfeiçoar o telescópio de refração (o perspicillium), muito mais poderoso do que qualquer outro da época, ele suscitou a seguinte reflexão: se há estrelas que não podem ser vistas a olho nu, deve haver muitas outras coisas que, apesar de existirem, não podemos enxergar. Essa proposição, provocada por uma nova tecnologia, foi revolucionária e mudou a maneira de pensar da época (KOYRÉ, s/d). A história das sociedades humanas pode ser explicada em uma sucessão de revoluções tecnológicas, onde cada época se estrutura nas anteriores e nos conhecimentos já adquiridos no decorrer das gerações. Como diria Ortega y Gasset (1989, p. 54), “o presente está feito com matéria do passado”. Portanto, um equipamento tecnológico se traduz em muito mais do que a atuação de uma sociedade sobre a natureza, ele reflete a forma de organização das relações internas entre seus membros e outros grupos sociais, o desenvolvimento econômico do grupo, as características e necessidades, um determinado estágio de conhecimento e até mesmo a maneira de se aprender em uma sociedade.

Desde o final do século passado, vivemos um novo paradigma tecnológico, que se organiza em torno das tecnologias da informação. Para Castells (1999, p. 50), “a revolução da tecnologia da informação é, no mínimo, um evento histórico da mesma importância que a Revolução Industrial do século XVIII", pois induziu um padrão de descontinuidade nas bases materiais da economia, sociedade e cultura, atingindo todos os domínios da atividade humana. E, assim como as fontes de energia foram o cerne do industrialismo, o ícone ou emblema da nova era tecnológica é a Internet. "Essas mídias, além de serem um dos principais negócios hodiernos, fazem parte de nossos objetos de uso fundamentais, assim como a indumentária, o mobiliário, a arquitetura, as ferramentas e máquinas de uso geral, tais como veículos, eletrodomésticos, etc.” 
(LOPES, 2004, p. 49). Para Lemos (2004, p. 25), "hoje, talvez mais que em outras épocas, a influência da tecnologia nas sociedades ocidentais tem um lugar capital dentre as questões que emergem como prioritárias na contemporaneidade".

Levy (1999, p. 13) diz que vivemos o segundo dilúvio, o das informações. De acordo com Oliveira, Barreiros e Cardoso (apud BENEYTO, 2002, 99), as novas tecnologias da informação e comunicação aumentaram a capacidade humana para se comunicar, para divulgar e receber informação e, inclusive, abriram o acesso ao conhecimento de maneira quase ilimitada, permitindo o surgimento de uma sociedade que não se prende ao espaço ou lugar determinado. Nas entrevistas realizadas, $90 \%$ dos participantes fez menção ao "enorme montante de informações em tempo real", "um mar sem fim de informações" que "dispensa que os usuários precisem manter muitas informações na cabeça ou que tenham memórias prodigiosas". Foi amplamente disseminada a ideia de que a qualquer instante podem consultar a rede em busca da informação desejada, de que na internet "tem tudo". Partindo-se desse pressuposto, inicia-se, então, uma relação bastante diferente com o saber, já que, mais do que ter conhecimento na memória, é preciso ter capacidade de gestão e articulação das informações, pois se, por um lado, a web serve de suporte para a memória, por outro, essa quantidade exorbitante de informações pode causar dificuldades para se encontrar uma informação determinada, ou ainda pode provocar o acesso a informações ambíguas, distorcidas, errôneas e até mesmo provocar uma confusão mental devido ao imenso número de informações. Os usuários citaram que, em assuntos específicos, podem ter dificuldades para obter a informação desejada e que um grande problema da net são as informações erradas ou até mesmo a dificuldade para se saber se são verdadeiras. Para Levy $(1999,93)$ a perspectiva da digitalização geral das informações provavelmente tornará o ciberespaço o principal canal de comunicação e suporte de memória da humanidade. Para Canavillas (2004), esse manancial de informação representa uma memória social, dinâmica, organizada e navegável”, ou seja, "a internet surge, naturalmente como uma extensão da memória.

\section{A memória, a internet e aprendizagem}

A memória, um dos elementos centrais do estudo, não se constitui apenas em capacidade mnemônica, nem muito menos em um simples arquivo de informações. Ela é, sobretudo, uma construção social, repleta de significações e peculiaridades, e tem 
estreito vínculo com as práticas sociais e a formação da identidade - um indivíduo é, em grande parte, aquilo de que se recorda. Quando falamos em memória, envolve-se a retenção e evocação de ideias, sensações, acontecimentos e conhecimentos adquiridos anteriormente de maneira seletiva. Dependemos dela para uma imensa gama de atividades cotidianas como lembrar um compromisso marcado, saber o que comemos no almoço, reconhecer a fisionomia das pessoas próximas, conseguir amarrar os sapatos, conversar com amigos, compreender o que os outros dizem, pensar, andar de bicicleta, reconhecer o perfume de uma flor, ficar com água na boca ao sentir cheiro de bolo quente, guardar rostos, cheiros, sons, comportamentos, paisagens... E também é fundamental para a aprendizagem. "A memória desempenha um papel tão abrangente no nosso cotidiano que só nos damos conta disso no momento em que um incidente provocado por um esquecimento ou distorção exige nossa atenção" (SCHACTER, 2003, p. 12).

A recordação é parte imprescindível de nossas vidas, passamos boa parte de nossa existência revivendo eventos passados mais antigos ou recentes, isso sem contar que as lembranças permeiam nosso pensamento constantemente. "Podemos afirmar que somos aquilo que recordamos, literalmente. Não podemos fazer aquilo que não sabemos como fazer, nem comunicar nada que desconheçamos, isto é, nada que não esteja em nossa memória" (IZQUIERDO, 2002, p. 09). O conjunto de memórias determina a personalidade de cada um, ou seja, tem relação intrínseca com a identidade das pessoas. Segundo Bosi (1999, p. 81), “um homem não sabe o que ele é se não for capaz de sair das determinações atuais". Um indivíduo será cuidadoso, aventureiro, receoso, impulsivo, introvertido ou contido mais de acordo com as suas lembranças, com o tipo de socialização a que foi submetido, do que com suas características genéticas. Esse fato é muito importante para ser considerado em ambientes de aprendizagem já que memórias boas de aprendizagem fazem o cérebro relacionar o aprender a prazer, facilitando a absorção de conhecimento e fazendo com que o aluno sinta que tem o perfil de quem gosta de aprender, que aprender é algo natural para ele. Há que se considerar ainda que o surgimento da Internet e a disseminação do seu uso provocaram novas formas de sociabilidade, pertencimento a novos grupos e isso interfere na identidade e na percepção dos indivíduos, podendo eles, mesmo vivendo em casas vizinhas, ter experiências bastante diversificadas.

Podemos ir ainda mais longe, afirmando que ter memória é uma questão de sobrevivência. Considerando o ser humano um ser gregário (não vive isoladamente), o 
qual necessita se comunicar, e que essa comunicação só é possível graças à memória, infere-se que ela é indispensável. Além disso, tudo o que apreendemos durante o processo de socialização depende da memória: aprendemos que se colocarmos o dedo na tomada levamos choques elétricos, que devemos ter cuidado com objetos cortantes pois nos causam ferimentos, que precisamos nos alimentar adequadamente. Isso sem contar que toda a evolução técnica está relacionada à memória, já que o desenvolvimento humano está em grande parte ligado ao entorno material, às tecnologias e ao conhecimento acumulado de cada época, que veio sendo transmitido ao longo das gerações. Por essas afirmações e muitas outras que poderiam ser expostas, consideramos a memória uma questão de sobrevivência.

Segundo Maurice Halbwachs (1990), a memória é coletiva, portanto social, e não podemos pensar nada em nós mesmos, senão pelos outros e para os outros. Fazemos apelo aos testemunhos alheios para fortalecer, debilitar ou também para completar o que sabemos de um evento. Como o homem se caracteriza por seu grau de integração no tecido das relações sociais, as suas lembranças se estabelecem e perduram somente na medida em que são narradas, confrontadas com a recordação de outros que participaram do evento, compartilhadas. "Um homem que se lembra sozinho o que os outros não se lembram assemelha-se a alguém que vê o que os outros não veem" (HALBWACHS, 1990). A memória, na visão de Halbwachs (1990), depende dos outros, ou melhor, dos grupos nos quais o indivíduo está inserido - a família, a escola, a classe social, a igreja, o trabalho, o clube etc. Por exemplo, recordamos nossa infância como membros da família, nosso período escolar como alunos de determinada escola, nosso bairro como pertencentes à comunidade local e assim por diante. Isso porque, de acordo com o autor, primeiro teórico da memória coletiva e discípulo de Durkheim, só há memória se houver comunicação, ou seja, uma constante confrontação do acontecimento. Guardamos um fato na memória quando ele é frequentemente debatido com outros elementos do grupo, caso contrário, suas marcas vão "desbotando" e acabam por deixar apenas vestígios ou apagar-se por completo. Levando em consideração que a internet expandiu as possibilidades de sociabilidade, é possível afirmar que, através da comunicação pela web, as memórias são "confrontadas" e essa é mais uma forma de perpetuar a lembrança.

A web chamada 2.0 possibilitou a interatividade - a possibilidade de opinar, participar e criar novos formatos que é oferecida a qualquer participante da rede. As mensagens deixaram de ser editadas por um centro para serem disseminadas de forma 
transversal, aleatória e associativa, ou, como prega Castells, em redes. Rodrigues (apud LEMOS, 2004, p. 80) afirma que "emissor e receptor fundem-se na dança de bits", passando de uma comunicação unidirecional (ainda que tenhamos que levar em consideração as diferentes recepções, já que um receptor nunca é passivo, pois recria e recombina a mensagem de acordo com seu repertório), para uma multidirecional, um sistema todos-todos. Uma das vantagens destacadas pelos internautas foi justamente a interatividade, "a possibilidade irrestrita de participação", a sensação de "liberdade por poder opinar", inclusive em assuntos que antes não se tinha acesso. Essa interatividade pode contribuir, sob a perspectiva de Halbwachs, para a perpetuação de lembranças na rede.

Há que se considerar ainda que a internet pode perpetuar memórias inclusive de fatos que não foram presenciados ao vivo. Quantas pessoas não têm em sua memória o episódio do ataque terrorista de 11 de setembro sem nunca ter sequer pisado nos Estados Unidos? No entanto, mesmo essas lembranças “emprestadas" passam a fazer parte da memória e formam nossa identidade. $70 \%$ dos entrevistados citaram o evento como uma lembrança marcante na internet. "Impossível não se emocionar com a história do 11 de setembro", "Sinto até hoje um aperto no peito quando me lembro das imagens vistas na internet em 11 de setembro", relataram.

A história a seguir ilustra a situação das lembranças emprestadas: $\mathrm{O}$ barbeiro pergunta ao sapateiro: "Lembra daquele rapaz, sempre atrasado, que costumava descer correndo a ladeira, com as malas nas costas, para pegar o trem das oito toda sextafeira?". "Claro que sim" - responde o sapateiro - "era um rapazote alto e magro que tinha os sapatos surrados e carcomidos, não é?". E o barbeiro completa: "Não sei, nunca reparei nos sapatos dele, mas os cabelos eram desalinhados e sem forma”. Da próxima vez que o barbeiro se lembrar do rapaz, além dos cabelos desalinhados, recordará dos sapatos carcomidos, o que significa dizer que o sapateiro acrescentou uma informação à memória do barbeiro e vice-versa. Assim, a lembrança ganha detalhes e se fortalece. Como diria Halbwachs, lembranças que têm com poucos pontos de contato com outras recordações têm mais dificuldade de perpetuação. Além disso, é importante observar que a memória interfere, inclusive, sobre a nossa percepção, ou seja, influencia nossa visão sobre a realidade. Essas duas informações, que a memória influencia a percepção e que lembranças que tenham poucos pontos de contanto com outras recordações são mais difíceis de lembrar, são de extrema importância quando se fala em aprendizagem. A convergência do aprendizado novo com conhecimentos consolidados, assim como 
conteúdos preparados levando em consideração a realidade dos alunos, facilita a retenção na memória.

Daniel Schacter (2003, p. 47), psicólogo norte americano e renomado estudioso da memória, concorda sobre esse ponto com Halbwachs, ele diz que pensar e falar sobre experiências não somente ajuda a compreender o passado como altera a capacidade de recordações posteriores e diz que os acontecimentos e incidentes que discutimos e repetimos estão protegidos, pelo menos parcialmente, contra a transitoriedade. Quando não refletimos ou falamos sobre o que aconteceu, a tendência é esquecer mais rapidamente. Evidentemente, as experiências que nos levam à reflexão e a discuti-las várias vezes podem ser apenas mais memoráveis (SCHACTER, 2003, p. 47). Para Schacter (2003, p. 15), a transitoriedade é uma característica básica da memória e está ligada ao enfraquecimento das lembranças com o passar do tempo, ou seja, é responsável por muitas das falhas de memória. Segundo o autor, as pessoas não têm dificuldades de se recordar o que fizeram nas últimas horas (só se tiverem problemas de memória), mas, com o passar do tempo, a dificuldade de se lembrar dos eventos vai aumentando progressivamente, a menos que sejam reforçadas de tempos em tempos. A confrontação de eventos para perpetuação na memória pode ser facilmente verificado no dia-a-dia, em reuniões de famílias ou encontros de amigos. E essa repetição, a retomada dos fatos, é importante para aprender, reter informações, memorizar. Nesse sentido, percebemos que muitos fatos e até memes da internet, justamente pela repetição, têm grande possibilidade de ficarem marcados na memória.

\section{Lapsos e perpetuadores da memória}

Quem já não perdeu as chaves e a encontrou no bolso, quem não procurou os óculos e os achou depois de muito na própria cabeça, quem já não cruzou com um conhecido e não conseguiu se lembrar do nome da pessoa, quem já não se esqueceu de um compromisso, do rosto de alguém, de passar um recado? Os lapsos da memória, embora desagradáveis, são características desejáveis e adaptativas da mente humana, que a fazem funcionar bem. Conforme Schacter (2003, p. 14), "os erros da memória são tão fascinantes quanto importantes". A memória é seletiva, não guardamos na memória tudo o que vivemos, apenas o que é relevante. Imaginemos, por exemplo, se todas as vezes que ouvíssemos a palavra "cadeira" nos viessem à mente, em poucos segundos, todas as experiências que já tivemos com uma cadeira durante toda a vida. 
Provavelmente existiriam milhares de incidentes dos mais diversos tipos e isso resultaria em uma imensa confusão, da qual não conseguiríamos obter a informação necessária. A memória inteligente é a memória que sabe esquecer (IZQUIERDO, 2004, p. 19). Por isso, Segundo Schacter (2003, p. 29), com o passar do tempo há "uma troca gradual de reprodução de detalhes e recordações específicas pela reconstrução e descrição mais geral de um evento". Halbwachs (1990, p. 72), por sua vez, afirma que temos a tendência de agrupar as memórias mais antigas em blocos. Por exemplo, posso não me recordar da minha chegada na escola no dia 26 de março de 1992, mas me lembro de outros dias que me parecem iguais àquele. Recordo-me que aquele ano foi o último que cursei em determinada escola, meus amigos da época, entre outras coisas, e imagino como deve ter sido tal dia. Para a consolidação do conhecimento, também é preciso levar isso em consideração, os detalhes vão perdendo a cor, esmaecendo na memória, por isso é preciso reforçar os pilares, para que o essencial não seja perdido. Metade dos entrevistados diz não se lembrar com detalhes sobre a primeira vez que entraram na internet, datas aproximadas, cenas já esmaecidas na memória, mas não se esqueceram do sentimento de "surpresa", "medo do desconhecido" e da sensação de que aquilo seria revolucionário.

Os mecanismos adaptativos da memória, embora indispensáveis, são os causadores dos lapsos. Schacter (2003), enumera os "pecados da memória" que considera mais relevantes para a ocorrência de falhas de memória e, por outro lado, de que maneira são benéficos para o funcionamento do cérebro. $\mathrm{O}$ primeiro deles é exatamente esse: a transitoriedade, ou seja, o enfraquecimento da memória com o tempo, já que o passado desaparece inevitavelmente com a ocorrência de novas experiências. Lembramos com detalhes o que fizemos na manhã de hoje ou no dia de já com relação aos acontecimentos da semana anterior, somos mais gerais ao descrevê-los, não sabemos tantos detalhes, nos enganamos sobre a ordem dos fatos ou o dia exato em que ele aconteceu, lembramo-nos mais das atividades atípicas, que desviaram a rotina diária. Outro pecado da memória é a distração. Na verdade, não é uma falha da memória, mas um lapso que resulta no esquecimento de informações que nunca foram codificadas de maneira adequada e ficam indisponíveis na hora que precisamos dela. É o caso de quando, absorto em uma conversa ao telefone, o indivíduo coloca seus óculos na poltrona e, mais tarde, ao resolver retomar sua leitura, ficar horas à procura deles, tentando relembrar onde os deixou. Como ele não havia codificado adequadamente a informação, pois estava distraído com a conversa, não havia como resgatá-la 
posteriormente. Eis porque, em ambientes de aprendizagem, a atenção é fator primordial, já que não há como haver recordação de algo que não foi registrado. Na internet, o grande problema de concentrar a atenção dos indivíduos é a enorme variedade de estímulos, que fazem com que os usuários acabem perdendo o seu foco inicial. "Abro milhões de páginas ao mesmo tempo, pulo de link em link e muitas vezes acabo me perdendo, até esquecendo o que eu estava fazendo". "Às vezes, você está fazendo alguma coisa, vem uma mensagem do WhatsApp ou do Facebook e aí já era, esquece tudo que ia fazer". $40 \%$ dos entrevistados relataram situações similares nesse sentido.

Além da confrontação, da retomada frequente das informações, da atenção no momento da formação da lembrança, da associação com outros pontos de contato da memória, há outros fatores que concorrem para uma melhor perpetuação da memória. Entre eles destacamos três. O primeiro é a posição do indivíduo no grupo. Um aluno, por exemplo, tende a se lembrar melhor do professor do que o contrário (com exceção de alunos brilhantes ou muito bagunceiros, que se destacam entre os outros para o professor), os funcionários de uma grande empresa tendem a se lembrar mais do empregador do que vice-versa. O segundo fator perpetuador de memória é o espaço. Segundo Halbwachs (1990, p. 131) as imagens habituais do mundo exterior são inseparáveis do nosso eu. Nosso equilíbrio mental decorre, em grande parte, do fato de que objetos materiais com os quais estamos em contato diário mudam pouco, oferecendo uma imagem de estabilidade e permanência. $\mathrm{O}$ entorno material forma pontos de apoio para a memória ao refletir o grupo, sua organização, seus costumes e distintivos. Halbwachs afirma que uma mudança na cidade é muito mais significativa que uma guerra no país, pois, por mais que o grupo seja acometido por catástrofes, se a paisagem continuar a mesma, os homens se sentirão confortáveis. Agora, quando se arruínam os locais de referência das pessoas, isso pode ser prejudicial ao equilíbrio delas e dificultar a perpetuação de lembranças. No entanto, essa relação muda um pouco - ou muito - na era da web 2.0. O distante fica perto e, mesmo longe, as pessoas se sentem tocadas, estressadas ou receosas com fatos que não têm uma relação próxima com sua vida, mas que parecem ter.

O terceiro fator é a emoção. O internacionalmente conhecido neurocientista Antonio Damásio ressalta a importância dos sentimentos para o processo de memorização. "Elas (as emoções) têm uma grande influência na nossa capacidade de memorizar. Na maioria dos casos, tanto sentimentos negativos como positivos que 
acompanham determinado episódio, fazem com que ele seja gravado e relembrado mais facilmente" (DAMÁSIO apud COLAVITTI, 2003). Ele explica, entretanto, que emoções extremamente fortes, especialmente as negativas como um acidente, podem surtir efeito contrário, extinguindo-se da memória. O mesmo acontece com os momentos de dor intensa. "As mulheres jamais teriam um segundo filho se pudessem reviver a dor do parto" (DAMÁSIO, p. 2003). Halbwachs também evidencia o poder da emoção na perpetuação de recordações. 95\% das lembranças relatadas como mais marcantes vivências na internet foram recordações que podem ser classificadas como de grande impacto emocional: notícias de nascimento de filhos, conhecer alguém especial na internet, ficar sabendo do acidente de um amigo, conseguir um emprego almejado, entre outras.

Ivan Izquierdo (2004) e seu grupo de pesquisadores demonstraram em seus estudos que os mecanismos cerebrais que modulam a memória são mediados por neurotransmissores (como a serotonina, a dopamina e a noradrenalina) ou por hormônios (como a adrenalina, a betaendorfina, a vasopressina e os corticoides), evidenciando que tanto a formação como a evocação de memórias são extremamente sensíveis às emoções e aos estados de ânimo. Segundo Schacter (2003, p. 200), as experiências do cotidiano e estudos de laboratório revelam que incidentes de elevada carga emocional são mais lembrados do que eventos que não despertam emoções. $O$ efeito da emoção começa no momento em que a memória é criada, quando a atenção e a codificação determinam se uma experiência vai ser lembrada ou esquecida. Nesse sentido, vale ressaltar que os vídeos da web são um poderoso estímulo emocional, imagens chocantes de crianças subnutridas, tiroteios, guerras, assassinatos e, por outro lado, imagens de amor mãe e filho, atos de caridade, espetáculos musicais, todos eles estímulos fortes às emoções e com grandes possibilidades de retenção. Esses recursos audiovisuais, com emoções de impacto, podem ser um prato cheio para estímulos de aprendizagem.

\section{Internet como extensão da memória}

Em resumo, podemos considerar que a confrontação constante de um evento, a atenção concentrada sobre ele, a associação com outras memórias correlatas, a posição do indivíduo no grupo, as emoções despertadas no momento e o entorno material são perpetuadores da memória. A presença desses fatores, em maior ou menor grau, 
determina a intensidade e vividez ou, em contraposição, o esmaecimento de nossas recordações.

Retomando a ideia da internet como uma tecnologia comunicacional que está hoje fortemente arraigada ao cotidiano, invadindo praticamente todos os setores da vida e modificando hábitos e comportamentos, $100 \%$ dos entrevistados citaram que a internet transformou de forma "radical", "extremamente significativa", "profundamente" muitos dos seus hábitos cotidianos. Foram citadas mudanças em diversos procedimentos de trabalho, contratação de pessoal, agilidade de tarefas, para localizar cursos, mudanças na vida pessoal (aplicativos para correr, para buscar filho na escola, para organizar as contas, para pedir comida, para chamar um taxi), retomada de contato com amigos da infância, com parentes de longe, com familiares que não conheciam e até amizades e namoros desenvolvidos a partir da internet. No entanto, as mudanças mais citadas entre os entrevistados são "o hábito de passar a vida com um mobile à tiracolo, onde quer que se vá" e a "não separação entre os setores da vida", acrescentando que "hoje o trabalho invade a casa, o filho invade o trabalho, a vizinha, os amigos, a loja, o grupo da escola estão todos ali presentes, sempre com você".

Outra grande mudança de paradigma evidenciada foi com relação à apreensão de conhecimentos e no que se refere à relação com o aprender. $80 \%$ dos entrevistados citaram que se encantam com a "fabulosa", "fantástica", "maravilhosa", "infindável" quantidade de informações disponíveis na internet sobre todos os assuntos e que se mostram como "oportunidades de aprender sobre qualquer coisa", sejam as oportunidades de aprendizagem formal (com cursos on-line) ou informal por conta desse volume de dados. "Você pode aprender de tudo", relatam.

A maioria deles considera a Internet como uma extensão da memória pessoal, citando como uma fonte de informações para os mais diversos fins: "Você guarda na memória seletivamente, sabendo que, se precisar, está ali na Internet”. Tudo é procurado na internet, desde um assunto que concerne ao trabalho, como fazer algo, a vida de um personagem histórico para a tarefa escolar da filha, uma data comemorativa, uma imagem para uma campanha, um objeto que será utilizado numa cirurgia, um trabalho para o mestrado, fontes para fazer uma entrevista, textos, cursos... Diariamente, eles estão ligados à internet fazendo pesquisas, vendo tutoriais, assistindo a vídeos e utilizando esse conteúdo no seu dia-a-dia. Há uma visão disseminada de que a Internet dá mais "agilidade" às tarefas diárias e de que é uma fonte quase inesgotável de conhecimento. Vale ressaltar, entretanto, que os entrevistados disseram ser necessário 
utilizar a própria memória para articular as informações e disseram sentir que "a dificuldade hoje é a gestão dessa informação e a seleção do que é ofertado na rede".

Levando em consideração todas essas transformações, fica evidente que hoje observamos uma apropriação tão grande dos usuários pela internet que se verifica a criação de uma relação de forte dependência. Nos relatos, essa dependência fica bastante evidente. "Tem pessoas que, quando o computador dá pau ou o celular acaba a bateria, ficam paralisadas", "Acabar a bateria do celular é um estresse, porque você fica sem poder dar nem receber notícias de ninguém", "Não fico sem internet, já é parte de mim". "Se fico sem celular, parece que perdi um braço, ou os dois". Vale ressaltar a ideia de DeFleur e Ball-Rokeach (1993, p. 338), que dizem que a mídia é indispensável para sociedades atuais, para a organização social e a conduta de atividades essenciais como a produção e a integração. Segundo a "Teoria de Dependência de Mídia" desses autores (1993, p. 224-226), tal dependência ocorre, pois o indivíduo busca na mídia: compreensão - seja de si mesmo ou do mundo; orientação - que pode ser da sua ação individual (decidir o que comprar, como se manter saudável, etc.) ou de interação (como agir diante de situações novas, não rotineiras ou difíceis, como se comportar face a grupos de fora, entre outros); e ainda divertimento. De acordo com o que o indivíduo procura na mídia (compreensão, orientação, divertimento), ele terá uma recepção e uma interpretação diferente, ainda que a mensagem seja a mesma. DeFleur e Ball-Rokeach (1993) acreditam que a capacidade da mídia de fazer um indivíduo reter na memória um fato ou ser influenciado em seu comportamento depende de vários fatores: se o indivíduo é um selecionador ativo ou um observador casual - ou seja, se ele escolheu página da internet que está vendo, terá retenção muito maior da mensagem do que alguém que dá uma olhada em um site que um amigo está acessando -; a expectativa do receptor quanto à utilidade da informação; e o envolvimento com a mensagem. Ou seja, quanto maior o nível de provocação cognitiva (prender a atenção) ou afetiva (despertar emoções) de uma mensagem, maior a retenção dela. "Nossa hipótese é de que as pessoas que foram estimuladas cognitiva e afetivamente se empenharão em um tipo de cuidadoso processamento das informações que lhes permitirá recordar ou relembrar as informações após lhes serem expostas" (DEFLEUR; BALL-ROKEACH, 1993, p. 333).

Além disso, os autores citam que quanto maior o grau de ambiguidade ou conflitos no meio em que a pessoa se insere maior a necessidade de informação para criar significados estáveis. Por exemplo, a mídia tem grande influência em momentos críticos como catástrofes naturais, sublevações políticas, etc. "Admitimos que a 
dependência do indivíduo e do grupo face à mídia torna-se mais intensa quando o ambiente social é ambíguo, ameaçador e/ou em rápida mutação" (DEFLEUR; BALLROKEACH, 1993, p. 335). Como o ambiente em que vivemos hoje:

\begin{abstract}
Em uma sociedade como a nossa, onde mudar é a palavra de ordem, onde a vida social se acha em certo grau de trânsito, há uma ambiguidade crônica que leva as pessoas a criarem relações de dependência permanente com a mídia. Esta é uma situação assaz diferente da de muitas sociedades do passado, onde as pessoas podiam contar que as coisas permanecessem na mesma de um dia para o outro, até mesmo de uma geração para outra. (DEFLEUR; BALLROKEACH, 1993, 335)
\end{abstract}

Por fim, vale ressaltar que a própria mídia, para formar padrões de memória, alimenta-se repetidamente do imaginário e da memória social. As transformações econômicas, políticas, sociais, culturais e tecnológicas que marcam a nossa época produzem uma profunda instabilidade nas inúmeras representações que a sociedade constrói de si mesma. Considerando que sociedade e tecnologia têm estreito vínculo e se influenciam concomitantemente, vale ressaltar que o advento da internet provocou novas representações, formas de comunicar e interagir, modificou relações espaciotemporais e exerce grande influência sobre a vida das pessoas, já que está cada vez mais presente no cotidiano delas.

\title{
Considerações finais
}

A internet está cada vez mais presente na vida e memória das pessoas e tem importante papel na criação, manutenção e desenvolvimento do simbólico e até da vida social atualmente. Levando em consideração que o processo comunicacional é estruturante da vida social, percebe-se que, entre as representações mentais compartilhadas pelos indivíduos, há a presença marcante dela. Essa tecnologia foi amplamente apropriada por seus usuários e provocou uma mudança efetiva e extremamente marcante no cotidiano das pessoas, contaminando praticamente todos os setores da vida.

As transformações fomentadas por ela - como, por exemplo, as novas relações espacio-temporais, as diferentes formas de sociabilidade, o acesso fácil a grande número de informações e a ampliação da interatividade - modificaram de forma radical hábitos e comportamentos, as formas de comunicar, interagir e aprender, trazendo uma 
mudança de paradigmas, de visão de mundo. O medo e a insegurança relatados sobre o primeiro contato com essa tecnologia hoje se inverte: o medo é ficar sem ela. O que evidencia uma apropriação de forma tão contundente que causa dependência. Fica claro pelos depoimentos que os usuários procuram na rede compreensão, orientação e entretenimento e que têm, em grande parte, seus comportamentos atrelados a ela de forma bastante efetiva. Também não resta dúvida que, atualmente, a internet tem grande influência na formação da memória individual e social. A web vive em uma espécie de retroalimentação com a memória coletiva: influencia as memórias de seus usuários e, ao mesmo tempo, alimenta-se repetidamente do imaginário e da memória social.

\section{REFERÊNCIAS}

BENEYTO, José Vidal (org.). La ventana Global: ciberespacio, esfera pública mundial y universo mediático. Madrid: Taurus, 2002.

BOSI, Ecléa. Memória e sociedade: lembranças de velhos. 7ed. São Paulo: Cia das Letras, 1999.

CASTELLS, Manuel. A era da informação: economia, sociedade e cultura. v.1 A Sociedade em rede. São Paulo: Paz e Terra, 1999.

CASTELLS, Manuel. A era da informação: economia, sociedade e cultura. v. 2. A Sociedade em rede. São Paulo: Paz e Terra, 1999.

CANAVILHAS, João Messias. A Internet como memória. Disponível em: <http://bocc.ubi.pt>. Acesso em: 01 dez. 2016.

COLAVITTI, Fernanda. A memória e o caos digital. Disponível em:

<http://galileu.globo.com/edic/130/memo.htm>. Acesso em: 17 jul. 2017.

DEFLEUR, Melvin L.; BALL-ROKEACH, Sandra. Teorias da comunicação de massa. Rio de janeiro: Jorge Zahar, 1993.

HALBWACHS, Maurice. A memória coletiva. São Paulo: Vértice/Revista dos tribunais, 1990.

IZQUIERDO, Ivan. A voz da memória. Pesquisa Fapesp, no 99, maio, 2004.

IZQUIERDO, Ivan. Memória. Porto Alegre: Artmed, 2002.

KOYRÉ, Alexandre. Do mundo fechado ao universo infinito. São Paulo: Forense, s/d.

LEMOS, André. Cibercultura: tecnologia e vida social na cultura contemporânea.

Porto Alegre: Sulina, 2004.

RPGE- Revista on line de Política e Gestão Educacional, Araraquara, v.21, n.esp.3, p. 1638-1654, dez., 2017. 
LEVY, Pierre. Cibercultura. São Paulo: editora 34, 1999.

LEVY, Pierre. Tecnologias da inteligência: o futuro do pensamento na era da informática. São Paulo: editora 34, 2002.

LOPES, Luiz Carlos. O culto às mídias: Interpretação, cultura e contratos. São Paulo: Edufscar, 2004.

ORTEGA Y GASSET, José. Em torno a Galileu: esquema das crises. Petrópolis: Vozes, 1989.

SHACTER, Daniel L. Os sete pecados da memória: como a mente esquece e lembra. Rio de Janeiro: Rocco, 2003.

TRUJILLO, Victor. Pesquisa de mercado: qualitativa e quantitativa. São Paulo: Scortecci, 2001.

\section{Como referenciar este artigo}

ZWICKER, Melanie Retz Godoy dos Santos. Internet, memória e aprendizagem: tecnologias digitais e implicações na memória. Revista on line de Política e Gestão Educacional, Araraquara, v.21, n.esp.3, p. 1638-1654, dez., 2017. ISSN: 1519-9029.

Submetido em: 10/03/2017

Aprovado em: 10/08/2017 